\title{
Cytochrome P450 2E1 and Glutathione S-Transferase M1 Polymorphisms and Susceptibility to Hepatocellular Carcinoma
}

\author{
MING-WHEI YU,*,* ALICJA GLADEK-YARBOROUGH,\$ SINNABHATR CHIAMPRASERT, $\$$ \\ REGINA M. SANTELLA, $\$$ YUN-FAN LIAW," and CHIEN-JEN CHEN" \\ *Department of Public Health and ${ }^{\dagger}$ Institute of Epidemiology, College of Public Health, National Taiwan University, Taipei, Taiwan; ${ }^{5} \mathrm{Cancer}$ \\ Center and Division of Environmental Sciences, School of Public Health, Columbia University, New York, New York; and "Liver Unit, Chang- \\ Gung Memorial Hospital and Chang-Gung Medical College, Taipei, Taiwan
}

Background \& Aims: Genetic polymorphisms in enzymes involved in carcinogen metabolism have been found to influence susceptibility to cancer. The aim of this study was to examine whether cytochrome P450 2E1 (CYP2E1) and/or glutathione S-transferase M1 (GSTM1) genetic polymorphisms were related to susceptibility to hepatocellular carcinoma (HCC). Methods: Genotyping of CYP2E1 and GSTM1 was performed using the polymerase chain reaction on peripheral white blood cell DNA from 30 patients with HCC and 150 controls nested in a cohort study. Results: The c1/c1 genotype of CYP2E1, detected by Pstl or Rsal digestion, was found in $83.3 \%$ of patients with HCC and in $63.3 \%$ of controls $(P=0.034)$. Homozygosity for the $c 1 / c 1$ genotype significantly increased the risk of developing HCC in cigarette smokers ( $P=0.001)$ but posed no increased risk in those who never smoked. The HCC risk associated with cumulative exposure to cigarette smoke was also more striking in individuals who carried the $\mathrm{c} 1 / \mathrm{c} 1$ genotype. Habitual alcohol drinking modified the HCC risk of cigarette smoking among those with the c1/c1 genotype. No association with the risk of HCC was observed for the Dral polymorphism of CYP2E1 or for the GSTM1-null genotype. Conclusions: Polymorphisms of CYP2E1 may play an important role in cigarette smoking-related hepatocarcinogenesis.

$\mathbf{P}$ rimary liver cancer, largely hepatocellular carcinoma ( $\mathrm{HCC}$, is one of the most common fatal cancers in the world. It is particularly common in certain areas of Asia and sub-Saharan Africa, where the annual incidence of $\mathrm{HCC}$ in men is $>20$ per 100,000 persons. ${ }^{1}$ The principal reason for such a high incidence is chronic hepatitis $B$ virus (HBV) infection. ${ }^{1}$ Although a vast majority of $\mathrm{HCC}$ cases are attributable to chronic HBV infection, $\mathrm{HCC}$ is not an inevitable consequence of chronic infection with $\mathrm{HBV}$. There is considerable evidence suggesting that human hepatocarcinogenesis is a multistage process with the involvement of multiple risk factors. In addition to $\mathrm{HBV}$, many other possible etiologic factors, including hepatitis $C$ virus, ${ }^{2,3}$ aflatoxin exposure, ${ }^{4}$ alcohol consumption, cigarette smoking, ${ }^{5-8}$ familial tendency, ${ }^{6}$ and elevated serum level of endogenous testosterone, ${ }^{9}$ have been implicated in the development of HCC. Among environmental risk factors of $\mathrm{HCC}$ other than $\mathrm{HBV}$, cigarette smoking and alcohol drinking are the most common in the general population. Their relationships to the risk of HCC have been documented in Taiwan ${ }^{5-7}$ and other countries. ${ }^{8}$ However, the biological mechanisms underlying the action of cigarette smoking and alcohol drinking in the pathogenesis of HCC are not well understood.

Many chemicals in tobacco smoke have oncogenic potential. Most chemical carcinogens require metabolic activation for binding to DNA and other cellular macromolecules. Both cytochrome $\mathbf{P} 450$ s and glutathione S-transferases play a part in the activation and detoxification of certain procarcinogens in tobacco smoke. ${ }^{10,11}$ An increasing number of studies indicate that genetic polymorphisms in these enzymes are factors in individual susceptibility to cigarette smoking-related cancers. ${ }^{12-15}$ However, the association between genetically determined differences in these enzymes and HCC has not been reported previously.

Cytochrome P450 2E1 (CYP2E1) is induced by etha$\mathrm{nol}^{16}$ and is of critical importance in the metabolic activation of many low-molecular-weight carcinogens including $N$-nitrosamines. ${ }^{17} \mathrm{~N}$-Nitrosamines are ubiquitous in the environment, present in tobacco smoke, and formed endogenously in the stomach. ${ }^{18}$ There is persuasive evidence to support the hypothesis that carcinogenic $N$ nitrosamines are important factors in human cancer through ingestion by smoking as well as food. ${ }^{18}$ Induction of CYP2E1 by ethanol has been shown to increase

Abbreviations used in this paper: CYP2E1, cytochrome P450 2E1; GSTM1, glutathione S-transferase M1; PCR, polymerase chain reaction; RFLP, restriction fragment length polymorphism.

(C) 1995 by the American Gastroenterological Association 0016-5085/95/\$3.00 
the frequency of $\mathrm{HCC}$ in animals exposed to $N$-nitrosodimethylamine. ${ }^{19}$ Restriction fragment length polymorphisms (RFLPs) of the CYP2E1 gene were recently identified. $^{20-23}$ The RFLPs detected by $P_{s t} \mathrm{I}$ and $R s a \mathrm{I}$ digestion were associated with transcriptional regulation of gene expression. ${ }^{24}$ The other genetic polymorphism that is shown using restriction endonuclease DraI is located in intron 6. The association between this genetic polymorphism and susceptibility to lung cancer has been examined in two case-control studies. ${ }^{21,22}$

The glutathione S transferase M1 (GSTM1) enzyme is involved in detoxifying a number of carcinogenic electrophiles, such as the epoxides of polycyclic aromatic hydrocarbons, present in tobacco smoke. ${ }^{11}$ Individuals with a homozygous GSTM1-null type express no protein. This genotype has been associated with an increased risk of lung and bladder cancer. ${ }^{12-14}$

In this study, we examined whether genetic polymorphisms of CYP2E1 and/or GSTM1 were associated with HCC risk using a case-control study nested in a large cohort study of men in Taiwan where HCC is hyperendemic. We showed a strong interaction between a CYP2E1 genetic polymorphism and cigarette smoking in the development of $\mathrm{HCC}$. The role of habitual alcohol drinking in cigarette smoking-related hepatocarcinogenesis was also evaluated.

\section{Materials and Methods}

\section{Study Subjects}

A cohort of 4841 male, asymptomatic, long-term HBV carriers and 2501 male noncarriers 30-65 years of age was recruited from the Government Employee Central Clinics and the Liver Unit of Chang-Gung Memorial Hospital in Taiwan from August 1988 to June 1992. At recruitment, each study subject was personally interviewed to obtain information on demographic characteristics, habits of cigarette smoking and alcohol drinking, dietary consumption frequency, as well as personal and family history of various chronic diseases. Blood specimens, including white blood cells and serum, from the study subjects were also obtained and frozen at $-70^{\circ} \mathrm{C}$ until subsequent analysis. All study participants were tested for hepatitis $B$ surface antigen (HBsAg) and antibodies against hepatitis $C$ virus (anti-HCV). Serum HBsAg was assayed using a radioimmunoassay (Abbott Laboratories, North Chicago, IL). Anti-HCV was examined by a second-generation enzyme immunoassay (Abbott Laboratories).

Follow-up of the study subjects was performed through various channels: annual $\alpha$-fetoprotein measurement and ultrasonography examination, personal telephone interview, and data linkage with computer files of national death certification and cancer registry systems. After an accumulation of 27,900 person-years of follow-up, a total of 38 patients with HCC were identified. All of the patients with $\mathrm{HCC}$ were diagnosed on the basis of either pathological or cytological examinations or an elevated $\alpha$-fetoprotein level ( $\geq 400 \mathrm{ng} / \mathrm{mL}$ ) combined with at least one positive image on angiography, sonography, and/or computerized tomography. Four controls were selected for each patient from cohort members without HCC on the date the disorder was diagnosed in the patient. The controls were matched to the index patient on age ( \pm 5 years) and time of questionnaire interview and blood collection. Genotyping of the GSTM1 and CYP2E1 was performed on a total of 30 patients with HCC (78.9\%) and 150 controls (98.7\%) based on the availability of DNA samples.

\section{Laboratory Analyses}

DNA was isolated from peripheral white blood cells by standard ribonuclease and proteinase $\mathrm{K}$ treatment and phenol/ chloroform extractions. Samples of DNA $(10 \mu \mathrm{L}$ and $0.1 \mu \mathrm{g} /$ $\mu \mathrm{L}$ ) were added to the polymerase chain reaction (PCR) mixture containing $61.5 \mu \mathrm{L}$ of autoclaved ultrafiltered water, 10 $\mu \mathrm{L}$ of $10 \times$ reaction buffer $\left(15 \mathrm{mmol} / \mathrm{L} \mathrm{MgCl}_{2} ; 100 \mathrm{mmol} / \mathrm{L}\right.$ Tris-HCl, pH 8.3; $500 \mathrm{mmol} / \mathrm{L} \mathrm{KCl}$; and $0.01 \%$ gelatin), $2 \mu \mathrm{L}$ $(10 \mathrm{mmol} / \mathrm{L})$ of each deoxynucleoside triphosphate (Boehringer Mannheim, Indianapolis, IN), $5 \mu \mathrm{L}$ (100 pmol) of each primer, and $0.5 \mu \mathrm{L}(5 \mathrm{U} / \mu \mathrm{L})$ of amplification Thermus aquaticus DNA polymerase (Boehringer Mannheim). The amplification was obtained using 35 thermal cycles as follows: 1 minute at $94^{\circ} \mathrm{C}$ for denaturation, 1 minute at $55^{\circ} \mathrm{C}$ for annealing, and 1 minute at $72^{\circ} \mathrm{C}$ for primer extension.

Separate PCRs were used to amplify the transcription regulation region of CYP2E1 that includes the enzyme recognition site for both PstI and RsaI and to amplify intron 6, which includes the DraI recognition site. The oligonucleotides used in the PCR reactions were complementary to the following sequences in these two regions of the CYP2E1 gene: primers (5'-CCAGTCGAGTCTACATTGTCA) $1370-1349$ and (5'TTCATTCTGTCTTCTAACTGG) 999-978 for $P_{s t} \mathrm{I}$ and $R s a \mathbf{I}$ sites $^{23}$ and primers (5'-TCGTCAGTTCCTGAAAGCAGG) $7367-7387$ and (5'-GAGCTCTGATGCAAGTATCGCA) 8340-8361 for the DraI site. ${ }^{25}$ A portion of the PCR-amplified product $(20 \mu \mathrm{L})$ underwent restriction enzyme digestion for 18 hours at $37^{\circ} \mathrm{C}$. All restriction enzymes and digestion buffers were from Promega (Madison, WI). The GSTM1 genotyping for gene deletion was performed by PCR amplification with primers for exons 6 and 7, which produced a 210-base pait band according to the method of Bell et al. ${ }^{13}$ Amplification of the $\beta$-globin gene was used as an internal control and produced a 268-base pair band. Samples were analyzed by electrophoresis in agarose gels (2.2\% for CYP2E1 and $4 \%$ for GSTM1) in Tris-acetate-ethylenediaminetetraaceric acid buffer (40 mmol/L Tris-acetate and $1 \mathrm{mmol} / \mathrm{L}$ ethylenediaminetetraacetic acid, $\mathrm{pH} 8.0$ ). A 100 -base ladder was used as a size marker.

\section{Statistical Methods}

The $\chi^{2}$ test was used to examine the differences in the distributions of genotypes studied between patients and controls. The odds ratio and its $95 \%$ confidence intervals were 
computed to compare the risk between levels of the categorical variables. The correlation between two categorical variables was measured by the contingency coefficient. Mantel's $\chi^{2}$ test for a trend was used to examine the dose-response relationship. The Mantel-Haenszel test for the homogeneity of odds ratios across strata was calculated as a test for interaction. For values of zero in any cross tables, 0.5 was added to each cell to derive the odds ratio according to the method described by Haldane and Anscombe ${ }^{26}$; the lower limit of $95 \%$ confidence interval for the odds ratio was calculated from the exact conditional distribution. All statistical tests were based on two-tailed probability.

\section{Results}

The ages (mean $\pm \mathrm{SD}$ ) of patients with HCC and controls were $51.9 \pm 10.2$ years and $51.6 \pm 9.5$ years, respectively. Almost all patients with $\mathrm{HCC}$ were $\mathrm{HBsAg}$ carriers; the $1 \mathrm{HBsAg-negative} \mathrm{patient} \mathrm{was} \mathrm{anti-HCV-}$ positive. Because a high proportion of HBsAg carriers were recruited into the study cohort, one half of the controls $(49.3 \%)$ were also $\mathrm{HBsAg}$ carriers. Anti-HCV was detected in 5 of 30 patients with HCC (16.7\%) and only 6 of 150 controls (4.0\%). Among the patients with HCC, $53.3 \%$ were Fukien Taiwanese, $10.0 \%$ Hakka Taiwanese, and $36.7 \%$ were mainland Chinese who either migrated themselves or whose parents migrated to Taiwan after World War II. The distribution of the ethnic groups was similar in patients with HCC and controls.

There were three genotypes of CYP2E1 resulting from
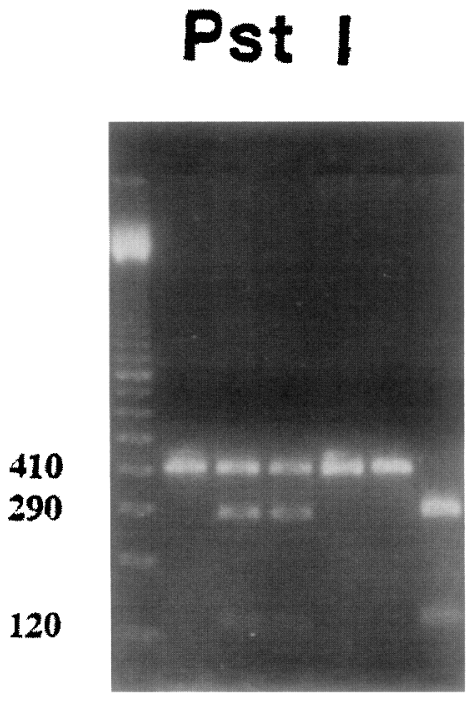

$\begin{array}{llllll}1 & 2 & 3 & 4 & 5 & 6\end{array}$
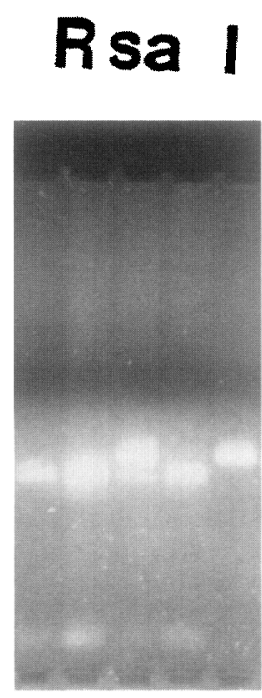

$\begin{array}{lllll}1 & 2 & 3 & 5\end{array}$
Figure 1. RFLPS of PCR-amplified fragments obtained with Pstl and $R$ sal. Samples were analyzed by agarose gel electrophoresis $(2.2 \%)$. The three possible genotypes are shown. Pstl: lanes 1, 4, and 5, type $\mathrm{A}(\mathrm{c} 1 / \mathrm{c} 1)$; lanes 2 and 3 , type $\mathrm{B}(\mathrm{c} 1 / \mathrm{c} 2)$; and lane 6 , type $\mathrm{C}(\mathrm{c} 2)$ c2). Rsal: lanes 1, 2, and 4, type A (c1/c1); lane 3, type B (c1/c2); and lane 5 , type $C(\mathrm{c} 2 / \mathrm{c} 2)$.

\section{Dra I}

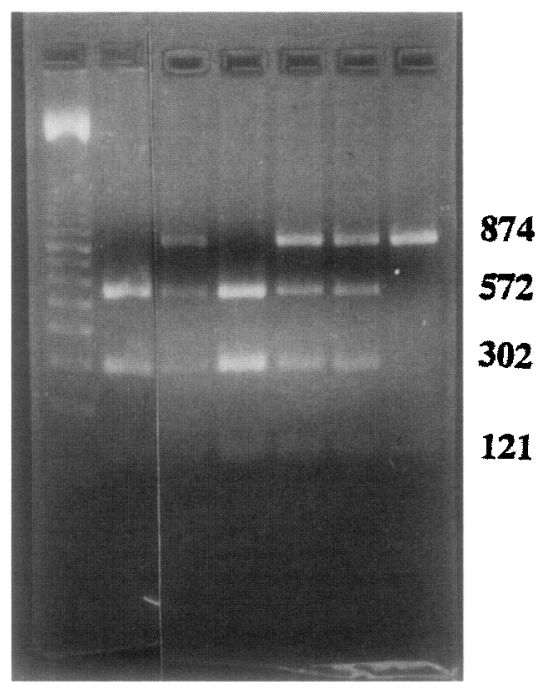

$\begin{array}{llllll}1 & 2 & 3 & 4 & 5 & 6\end{array}$

Figure 2. RFLPS of PCR-amplified fragments that underwent a Dral restriction enzyme digestion. Samples were analyzed by agarose gel electrophoresis (2.2\%). Lanes 1 and 3, genotype DD; lanes 2, 4, and 5 , genotype $\mathrm{CD}$; lane 6 , genotype $\mathrm{CC}$.

digestion with restriction enzymes Pst or RsaI: type A, a predominant homozygote $\mathrm{cl} / \mathrm{cl}$; type $\mathrm{B}$, the heterozygote $\mathrm{c} 1 / \mathrm{c} 2$; and type $\mathrm{C}$, a rare homozygote $\mathrm{c} 2 / \mathrm{c} 2$ (type C) (Figure 1). Identification of the genotype by $P_{s t} \mathrm{I}$ or $R s a$ I was identical as described previously. ${ }^{23}$ In the PCRbased RFLP analysis of CYP2E1 by DraI digestion, individuals were divided into three genotypes, including heterozygotes (CD) and two homozygotes (DD and a minor CC) (Figure 2).

Table 1 shows the frequencies of CYP2E1 and GSTM1 genotypes in patients with HCC and controls. The rare homozygous $\mathrm{c} 2 / \mathrm{c} 2$ genotype detected by $P s t \mathrm{I}$ or $R s a \mathrm{I}$ digestion of CYP2E1 was found in 6 of 150 controls $(4.0 \%)$ but in none of the patients with HCC. There was a significant trend for the odds ratios of developing HCC with an increasing number of the $c 1$ allele $(P=0.029$, be homozygous for the $P_{s t} \mathrm{I}$ (or $R_{s a} \mathrm{I}$ ) genotype $\mathrm{c} 1 / \mathrm{c} 1$ than controls. The odds ratio of $\mathrm{HCC}$ for the $\mathrm{c} 1 / \mathrm{cl}$ genotype compared with two other genotypes combined was 2.9 (95\% confidence interval, $1.0-8.0 ; P=0.034$ ). Individuals with the $\mathrm{D}$ allele detected by DraI digestion of CYP2E1 seemed to have a higher risk of developing HCC, but the DraI genotype was not significantly associated with HCC. The frequency of the GSTM1-null genotype was slightly lower in patients with HCC (53.3\%) than in controls (63.3\%). The GSTM1-null genotype was also not significantly associated with HCC. 
Table 1. Frequencies of CYP2E1 and GSTM1 Genotypes Among 30 Patients With HCC and 150 Controls in Taiwan

\begin{tabular}{|c|c|c|c|c|}
\hline Genotype & $\begin{array}{l}\text { No. of } \\
\text { controls } \\
\text { (\%) }\end{array}$ & $\begin{array}{l}\text { No. of } \\
\text { patients } \\
(\%)\end{array}$ & $\begin{array}{l}\text { Odds } \\
\text { ratio }\end{array}$ & $\begin{array}{l}\text { Odds ratio } \\
\text { (95\% Cl) }\end{array}$ \\
\hline \multicolumn{5}{|l|}{$\begin{array}{l}\text { Pstl (or Rsal) } \\
\text { genotype of } \\
\text { CYP2E1 }^{a}\end{array}$} \\
\hline $\mathrm{c} 2 / \mathrm{c} 2$ & $6(4.0)$ & $0(0.0)$ & $\left.1.0^{b}\right\}$ & \multirow{2}{*}{1.0} \\
\hline $\mathrm{c} 1 / \mathrm{c} 2$ & $49(32.7)$ & $5(16.7)$ & $1.4\}$ & \\
\hline $\mathrm{c} 1 / \mathrm{c} 1$ & $95(63.3)$ & $25(83.3)$ & $3.5^{\prime}$ & $2.9(1.0-8.0)^{c}$ \\
\hline \multicolumn{5}{|l|}{$\begin{array}{l}\text { Dral genotype of } \\
\text { CYP2E1 }\end{array}$} \\
\hline $\mathrm{CC}$ & $10(6.9)$ & $1(3.5)$ & 1.0 ? & \multirow[b]{3}{*}{$1.6(0.7-3.9)$} \\
\hline $\mathrm{CD}$ & $46(31.5)$ & $7(24.1)$ & $1.5\}$ & \\
\hline $\mathrm{DD}$ & $90(61.6)$ & $21(72.4)$ & $2.3^{J}$ & \\
\hline \multicolumn{5}{|l|}{ GSTM1 } \\
\hline$+/+$ and $+/ 0$ & $55(36.7)$ & $14(46.7)$ & & 1.0 \\
\hline $0 / 0$ & $95(63.3)$ & $16(53.3)$ & & $0.7(0.3-1.5)$ \\
\hline
\end{tabular}

NOTE. One patient and four controls provided no information on Dral genotype because of insufficient DNA samples.

$\mathrm{Cl}$, confidence interval.

${ }^{a}$ PstI and Rsal RFLPs were completely associated with each other. ${ }^{\circ} P=0.029$, test for trend.

${ }^{c} P=0.034$.

A large degree of correlation was observed between RFLPs after PstI (or RsaI) and DraI digestion of CYP2E1. Most of the subjects with the $c 1 / c 1$ genotype by $P_{s} t \mathrm{I}$ or RsaI digestion carried the DraI DD genotype (86.3\%), whereas most of the subjects with the $\mathrm{c} 1 / \mathrm{c} 2$ genotype carried the Dral CD genotype (69.8\%). All subjects with the $c 2 / \mathrm{c} 2$ genotype by $P s t \mathrm{I}$ or $R s a \mathrm{I}$ digestion carried the DraI CC genotype. The contingency coefficient of the two RFLPs was $0.61(P<0.01)$ in patients with HCC and $0.68(P<0.01)$ in controls, respectively. The odds ratios of HCC associated with the combined genotypes of the Pst (or RsaI) and DraI polymorphisms of CYP2E1 are shown in Table 2. Persons who carried the $\mathrm{c} 1 / \mathrm{c} 1$ genotype of CYP2E1 by PstI or RsaI digestion had a higher risk of HCC than those with the $\mathrm{c} 1 / \mathrm{c} 2$ or $\mathrm{c} 2 / \mathrm{c} 2$ genotype regardless of their $D \mathrm{raI}$ genotypes. Individuals with the $\mathrm{c} 1 / \mathrm{c} 1$ genotype had about a 2.5 -fold increase in their risk of HCC relative to those with the combinations of other genotypes. No material difference in HCC risk was observed between individuals with the Pst I (or RsaI) c1/c1 genotype who had a Dral DD genotype and those who were the DraI CD heterozygotes.

Both GSTM1-null and GSTM1-nonnull patients with HCC were more likely to carry the PstI (or RsaI) c1/c1 genotype of CYP2E1 than their corresponding controls (Table 3). The odds ratios of HCC associated with the PstI (or $R s a \mathrm{I}$ ) c1/c1 genotype were not significantly different between GSTM1-null and GSTM1-nonnull individuals ( $P=0.8$, test for homogeneity).
Because CYP2E1 and GSTM1 may play an important role in the metabolism of tobacco smoke-derived carcinogens, the risk of HCC associated with the polymorphisms of the two enzymes may depend on the individuals' smoking status. Among nonsmokers, there was essentially no difference in the PstI (or RsaI) polymorphism of CYP2E1 between patients with HCC and controls. Among smokers, the frequency of the $\mathrm{c} 1 / \mathrm{cl}$ genotype of CYP2E1 was significantly greater in patients with HCC than in controls, showing an odds ratio of 24.3 (95\% confidence interval, 2.4 to infinity; $P=$ $0.001)$. The upper limit of the $95 \%$ confidence interval for the odds ratio was infinity because of the fact that no patients with $\mathrm{HCC}$ who smoked carried the $\mathrm{c} 1 / \mathrm{c} 2$ or $\mathrm{c} 2 / \mathrm{c} 2$ genotypes. A test for statistical interaction between cigarette smoking and the $\mathrm{cl} / \mathrm{c} 1$ genotype was significant based on a multiplicative model ( $P=0.007$, test for homogeneity). No association between the GSTM1-null genotype and HCC risk was observed either in nonsmokers or in smokers (Table 4).

Table 5 shows the odds ratios of HCC associated with cumulative exposure to cigarette smoking among individuals homozygous for the $P_{s t} \mathrm{I}$ (or $R s a \mathrm{I}$ ) $\mathrm{cl} / \mathrm{c} 1$ genotype and those with the GSTM1-null genotype. Compared with nonsmokers, the odds ratio of developing $\mathrm{HCC}$ for every level of smoking exposure was more striking in individuals carrying the $P_{s t} \mathrm{I}$ (or $R s a \mathrm{I}$ ) $\mathrm{c} 1 / \mathrm{c} 1$ genotype of CYP2E1 than in GSTM1-null individuals. A significant dose-response relationship between pack-years of cigarette smoking and $\mathrm{HCC}$ risk was observed among individuals with the $\mathrm{cl} / \mathrm{c} 1$ genotype of CYP2E1 $(P=0.02$, test for trend). In contrast, there was no significant association between cumulative exposure to cigarette smoke and HCC among GSTM1-null individuals.

CYP2E1 is characterized by its ethanol inducibility and metabolism of alcohols. ${ }^{16}$ The data in Table 6 show

Table 2. Odds Ratios of HCC Associated With the Combinations of the Pstl (or Rsal) and Dral Genotypes of CYP2E1

\begin{tabular}{|c|c|c|c|c|}
\hline $\begin{array}{c}\text { Pstl (or Rsal) } \\
\text { and Dral } \\
\text { genotype }\end{array}$ & $\begin{array}{c}\text { No. of } \\
\text { controls } \\
(\%)\end{array}$ & $\begin{array}{c}\text { No. of } \\
\text { patients } \\
(\%)\end{array}$ & $\begin{array}{l}\text { Odds } \\
\text { ratio }\end{array}$ & $\begin{array}{c}\text { Odds ratio } \\
(95 \% \mathrm{Cl})\end{array}$ \\
\hline $\mathrm{c1} / \mathrm{C} 2 \quad \mathrm{CD}$ & $33(22.6)$ & $4(13.8)$ & $1.0)$ & \multirow{3}{*}{1.0} \\
\hline $\mathrm{c} 1 / \mathrm{c} 2 \mathrm{DD}$ & $10(6.8)$ & $0(0.0)$ & 0.4 & \\
\hline $\begin{array}{l}c 1 / c 2 \text { or } \\
\mathrm{c} 2 / \mathrm{c} 2 \mathrm{CC}\end{array}$ & $10(6.8)$ & $1(3.4)$ & 1.1 & \\
\hline$c 1 / c 1 \quad C D$ & $13(8.9)$ & $3(10.3)$ & 1.9 & $2.4(0.5-11.6)$ \\
\hline $\mathrm{c} 1 / \mathrm{c} 1 \quad \mathrm{DD}$ & $80(54.8)$ & $21(72.4)$ & 2.0 & $2.8(1.0-7.8)^{a}$ \\
\hline
\end{tabular}

NOTE. One patient and four controls provided insufficient DNA samples for genotyping of CYP2E1 by Dral digestion.

$\mathrm{Cl}$, confidence interval.

${ }^{\mathrm{a}} P=0.05$ 
Table 3. Risk of HCC Associated With the Pstl (or Rsal) Genotypes of CYP2E1 by GSTM1 Genotype

\begin{tabular}{|c|c|c|c|c|c|c|}
\hline \multirow[b]{2}{*}{$\begin{array}{l}\text { CYP2E1 Pstl (or } \\
\text { Rsal) genotype }\end{array}$} & \multicolumn{3}{|c|}{ GSTM $1+/+$ and $+/ 0$} & \multicolumn{3}{|c|}{ GSTM1 0/0 } \\
\hline & $\begin{array}{c}\text { No. of } \\
\text { controls (\%) }\end{array}$ & $\begin{array}{c}\text { No. of } \\
\text { patients (\%) }\end{array}$ & $\begin{array}{l}\text { Odds ratio } \\
(95 \% \mathrm{Cl})\end{array}$ & $\begin{array}{c}\text { No. of } \\
\text { controls (\%) }\end{array}$ & $\begin{array}{c}\text { No. of } \\
\text { patients (\%) }\end{array}$ & $\begin{array}{l}\text { Odds ratio } \\
(95 \% \mathrm{Cl})\end{array}$ \\
\hline $\mathrm{c} 1 / \mathrm{c} 2$ and $\mathrm{c} 2 / \mathrm{c} 2$ & $16(29.1)$ & $2(14.3)$ & 1.0 & $39(41.0)$ & $3(18.7)$ & 1.0 \\
\hline $\mathrm{c} 1 / \mathrm{c} 1$ & $39(70.9)$ & $12(85.7)$ & $2.5(0.5-12.3)$ & $56(59.0)$ & $13(81.3)$ & $3.0(0.8-11.3)$ \\
\hline
\end{tabular}

$\mathrm{Cl}$, confidence interval.

the effect of the combined contributions of habitual alcohol drinking, cigarette smoking, and CYP2E1 genotype to the risk of developing HCC. Compared with individuals carrying the $\mathrm{c} 1 / \mathrm{c} 2$ or $\mathrm{c} 2 / \mathrm{c} 2$ genotype of CYP2E1 who did not smoke or drink, a moderate excess risk of HCC was observed among those homozygous for the $\mathrm{cl} / \mathrm{cl}$ genotype who were smokers. A much greater risk was observed for the $\mathrm{c} 1 / \mathrm{c} 1$ homozygotes who were both smokers and drinkers.

\section{Discussion}

Taiwan is a hyperendemic area of HBV infection with an HBsAg carrier rate as high as $15 \%-20 \% .^{1,2}$ Long-term HBV infection has been well documented as the most important risk factor of HCC in Taiwan. ${ }^{2}$ However, HBV infection alone does not determine the development of HCC. Only a fraction of long-term HBV carriers are affected with $\mathrm{HCC}$ during their lifetime. The onset age of HCC among long-term HBV carriers also varies over a wide range from younger than 10 years old to older than 80 years old. These facts have stimulated the search for other environmental and host factors that may also contribute to the etiology of HCC.

Familial aggregation of HCC has been reported in high incidence areas of mainland China and Taiwan. ${ }^{6,27}$ Our previous study found that individuals with first- degree relatives affected with HCC had a higher risk of developing HCC after adjustment for long-term HBV carrier status. ${ }^{6}$ This familial tendency toward HCC may result from a common environment shared by familial members or from inherited genetic susceptibility. However, the genetic basis of HCC is less well understood than its environmental risk factors.

There is evidence suggesting that there may be a geneenvironment interaction in the development of cancer such that cancer risk associated with a given exposure is modified by the genotype of the host. ${ }^{12-15}$ CYP2E1 is characterized by its ethanol inducibility and metabolism of ethanol and other primary alcohols. ${ }^{16}$ Ethanol consumption has been associated with the development of HCC on the basis of numerous epidemiological studies using various study designs. ${ }^{5,6,8}$ CYP2E1 catalyzes oxidation and DNA adduct formation of many low-molecularweight carcinogens, such as $N$-nitrosamines, vinyl chloride, and urethane. ${ }^{17}$ It is a major enzyme responsible for metabolic activation of tobacco-related nitrosamines in human liver microsomes. ${ }^{28}$ Nitrosamines are potent carcinogens in many animal species and have been linked with various human cancers. ${ }^{18}$ In animal models, longterm low-dose exposure to $N$-nitrosamines was associated with HCC. ${ }^{29}$ Induction of CYP2E1 by ethanol has also been shown to increase the frequency of HCC in rats

Table 4. Risk of HCC in Relation to the Pstl (or Rsal) Genotypes of CYP2E1 and GSTM1 Genotypes by Cigarette Smoking Status

\begin{tabular}{|c|c|c|c|c|c|c|}
\hline \multirow[b]{2}{*}{ Genotype } & \multicolumn{3}{|c|}{ Nonsmokers } & \multicolumn{3}{|c|}{ Smokers } \\
\hline & $\begin{array}{c}\text { No. of } \\
\text { controls }(\%)\end{array}$ & $\begin{array}{c}\text { No. of } \\
\text { patients (\%) }\end{array}$ & $\begin{array}{l}\text { Odds ratio } \\
(95 \% \mathrm{Cl})\end{array}$ & $\begin{array}{c}\text { No. of } \\
\text { controls }(\%)\end{array}$ & $\begin{array}{l}\text { No. of } \\
\text { patients (\%) }\end{array}$ & $\begin{array}{l}\text { Odds ratio } \\
(95 \% \mathrm{Cl})\end{array}$ \\
\hline \multicolumn{7}{|c|}{$\begin{array}{l}\text { Pstl (or Rsal) genotype } \\
\text { of CYP2E1 }\end{array}$} \\
\hline $\mathrm{c} 1 / \mathrm{c} 2$ and $\mathrm{c} 2 / \mathrm{c} 2$ & $29(30.5)$ & $5(29.4)$ & 1.0 & $26(47.3)$ & $0(0.0)$ & 1.0 \\
\hline $\mathrm{c} 1 / \mathrm{c} 1$ & $66(69.5)$ & $12(70.6)$ & $1.1^{a}(0.3-3.3)$ & $29(52.7)$ & $13(100.0)$ & $24.3^{b, c}(2.4$ to infinity) \\
\hline \multicolumn{7}{|l|}{ GSTM1 } \\
\hline$+/+$ and $+/ 0$ & $34(35.8)$ & $7(41.2)$ & 1.0 & $21(38.2)$ & $7(53.8)$ & 1.0 \\
\hline $0 / 0$ & $61(64.2)$ & $10(58.8)$ & $0.8(0.3-2.3)$ & $34(61.8)$ & $6(46.2)$ & $(0.2-1.8)$ \\
\hline
\end{tabular}

${ }^{a}$ Test for homogeneity of the odds ratios across cigarette smoking status was significant; $P=0.007$.

${ }^{b}$ Test of significance and the $95 \%$ confidence interval of odds ratio were based on the exact conditional distribution.

${ }^{c} P=0.001$. 
Table 5. Risk of HCC Associated With Cumulative Exposure to Cigarette Smoking

\begin{tabular}{lccccc}
\hline & \multicolumn{2}{c}{ Pstl (or Rsal) c1/c1 genotype of CYP2E1 } & & GSTM1 0/0 \\
\cline { 2 - 3 } \cline { 5 - 6 } Smoking exposure & Controls ${ }^{b} /$ patients & Odds ratio $(95 \% \mathrm{Cl})$ & & Controls/patients & Odds ratio $(95 \% \mathrm{Cl})$ \\
\hline Nonsmokers & $66 / 12$ & $1.0^{c}$ & $61 / 10$ & 1.0 \\
$1-17.4$ pack-years & $15 / 5$ & $1.8(0.6-6.0)$ & $16 / 3$ & $1.1(0.3-4.7)$ \\
$17.5-29.2$ pack-years & $7 / 4$ & $3.1^{d}(0.8-12.4)$ & $8 / 1$ & $0.8(0.1-6.8)$ \\
$\geq 29.3$ pack-years & $6 / 4$ & $3.7^{e}(0.9-15.0)$ & $10 / 2$ & $1.2(0.2-6.4)$ \\
\hline
\end{tabular}

Cl, confidence interval.

${ }^{a}$ The median (17.5 pack-years) and 75th percentile (29.3 pack-years) of the cumulative doses of cigarette smoking in non-HCC smokers were used as cutpoints.

${ }^{b}$ One control had no data on cigarettes smoked per day.

${ }^{c} P=0.02$, test for trend.

${ }^{a p}=0.090$.

${ }^{e} P=0.057$.

exposed to $N$-nitrosodimethylamine. ${ }^{19}$ Thus, it is interesting to investigate the role of CYP2E1 genetic polymorphisms in cigarette smoking - and alcohol drinkingrelated hepatocarcinogenesis. Of particular interest is the synergistic relationship shown between ethanol consumption and tobacco use in the development of HCC.

In this study, we showed a significant association between genetically determined differences in CYP2E1 and HCC risk. Individuals found to be homozygous for the c1/c1 genotype of CYP2E1 using PstI or RsaI digestion showed a much higher risk of HCC than those who were heterozygotes or carried a rare homozygous $c 2 / c 2$ genotype. This association was only present in cigarette smokers and not in those who had never smoked. Because all the patients with HCC who smoked in this study carried the $\mathrm{cl} / \mathrm{c} 1$ genotype, the upper limit of the $95 \%$ confidence interval for the odds ratio of HCC associated with this genetic trait was infinity among smokers. This result can be taken to mean that a large proportion of cigarette smoking-related HCCs is attributable to the c1/c1 genotype of CYP2E1. Although there has been considerable controversy in the past about the relation- ship between cigarette smoking and HCC, most recent studies have implicated cigarette smoking as a major nonviral risk factor for $\mathrm{HCC}^{8}$ In this study, $\mathrm{HCC}$ risk was elevated with increasing pack-years of cigarette smoking. This dose-response relationship was observed only for subjects who only carried the $c 1 / c 1$ genotype. The results of this study support the role of cigarette smoking in hepatocarcinogenesis and extend previous findings to identify an inherited predisposition for developing HCC in relation to exposure to cigarette smoking.

There have been two case-control studies conducted to examine the association between CYP2E1 genotypes by DraI digestion and lung cancer. ${ }^{21,22}$ A significant association of the DraI polymorphism with lung cancer was reported in a Japanese case-control study. ${ }^{21}$ However, a recent case-control study performed in Finland failed to observe this association. ${ }^{22}$ The CYP2E1 RFLP detected by DraI digestion was closely associated with the RFLP of CYP2E1 by PstI or RsaI digestion in the present study. After taking into account the PstI (or $R_{s} \mathrm{I}$ ) CYP2E1 genotypes, the DraI polymorphism seems not to be a risk factor of HCC. In contrast, individuals with the $\mathrm{cl} /$

Table 6. Combined Risk of HCC Associated With Habitual Alcohol Drinking, Cigarette Smoking, and CYP2E1 Gene Polymorphism Detected by Pstl or Rsal Digestion

\begin{tabular}{|c|c|c|c|c|c|}
\hline $\begin{array}{l}\text { Habitual } \\
\text { alcohol drinking }\end{array}$ & $\begin{array}{l}\text { Cigarette } \\
\text { smoking }\end{array}$ & $\begin{array}{l}\text { Pstl (or Rsal) } \\
\text { c1/c1 genotype }\end{array}$ & $\begin{array}{l}\text { No. of } \\
\text { controls }\end{array}$ & $\begin{array}{l}\text { No. of } \\
\text { patients }\end{array}$ & $\begin{array}{l}\text { Odds ratio } \\
(95 \% \mathrm{Cl})\end{array}$ \\
\hline No or yes & No or yes & No & 55 & $5^{a}$ & $1.0^{b}$ \\
\hline No & No & Yes & 58 & 11 & $2.1(0.7-6.4)$ \\
\hline Yes & No & Yes & 8 & 1 & $1.4(0.1-13.3)$ \\
\hline No & Yes & Yes & 20 & 7 & $3.9(1.1-13.5)^{c, d}$ \\
\hline Yes & Yes & Yes & 9 & 6 & $7.3(1.8-29.2)^{c, e}$ \\
\hline
\end{tabular}

$\mathrm{Cl}$, confidence interval.

${ }^{a}$ No patients with $\mathrm{HCC}$ who carried the $\mathrm{c} 1 / \mathrm{c} 2$ or $\mathrm{c} 2 / \mathrm{c} 2$ genotype of CYP2E1 had a habit of cigarette smoking or alcohol drinking.

${ }^{b} P=0.005$, test for trend.

'Statistical analyses were performed by Fisher's Exact Test.

${ }^{q} P=0.04$.

${ }^{e} p=0.006$. 
c1 genotype of CYP2E1 detected by $P_{s t} \mathrm{I}$ or $R s a \mathrm{I}$ had a greater risk of $\mathrm{HCC}$ regardless of their DraI genotypes. The polymorphism detected by DraI digestion is located in intron 6 , and no functional significance of this polymorphism is currently known. ${ }^{21}$ The PstI and RsaI restriction sites are in the transcription-regulation region of CYP2E1 that has been linked with gene expression. ${ }^{24}$ This may explain why the PstI or Rsal, rather than the DraI, polymorphisms of CYP2E1 were associated with HCC risk in this study. However, it is interesting to note that the transcriptional activity was 10 times greater in HepG2 cells with $c 2 / c 2$ genotype than cells with $\mathrm{cl} / \mathrm{cl}$ genotype in a study using the chloramphenicol acetyltransferase assay. ${ }^{24}$ This suggests that the transcriptional activity of the $c 2$ allele is greater than the activity of the $c 1$ allele. The reason why $c 1 / c 1$ homozygotes of CYP2E1 are more susceptible to HCC is not known. Data on the relationship between the genotypes and phenotypes of CYP2E1 in humans are limited. In the absence of environmental inducers, the constitutive expression of the CYP2E1 may be relatively low. It has been reported that a wide genetic variation exists in the responsiveness to the induction of CYP2E1 and that various agents may induce CYP2E1 through different mechanisms. ${ }^{30,31}$ The inducibility of CYP2E1 by cigarette smoking for individuals with different genotypes remains indeterminate.

Because CYP2E1 is a major enzyme for the metabolism of ethanol, the possible association between the genetic polymorphisms of CYP2E1 and alcoholic liver disease has also been investigated. However, the results are conflicting. One study showed that the $\mathrm{c} 1 / \mathrm{c} 1$ genotype was associated with an increased risk of liver cirrhosis in alcoholics, ${ }^{23}$ whereas another reported a significantly higher prevalence of the $c 2 / c 2$ genotype in patients with alcoholic liver disease than in heavy drinkers without alcoholic liver disease. ${ }^{32}$ Mechanistic explanations for why $\mathrm{c} 1 / \mathrm{c} 1$ homozygotes of CYP2E1 are more susceptible to HCC merits further study.

GSTM1 has broad substrate specificity, and presumably, the GSTM1-null genotype identifies detoxificationdeficient subjects with a cancer susceptibility syndrome. Although the specific carcinogens detoxified by GSTM1 are unknown, several polycyclic aromatic hydrocarbon epoxides generated from cigarette smoke are known substrates, including the potent carcinogen benzo[a]pyrene7,8-diol-9,10-oxide. ${ }^{11}$ Recent studies have observed consistently that cigarette smokers with the GSTM1-null genotype are at excess risk of developing lung and bladder cancers. ${ }^{12-14}$ In contrast, no such association was observed for HCC in this study.

Habitual alcohol drinking has long been postulated as a risk factor for HCC because of its hepatotoxic effects and its relationship to cirrhosis. ${ }^{33}$ However, it may also increase $\mathrm{HCC}$ risk without the presence of liver cirrhosis through a variety of mechanisms, such as induction of microsomal enzymes that activate procarcinogens, alteration of DNA repair and immunosurveillance system, as well as exacerbation of dietary deficiency. ${ }^{34}$ The relative importance of each of these mechanisms in the development of HCC remains to be elucidated. Habitual alcohol drinking and cigarette smoking may have independent effects on HCC risk, ${ }^{5,6,8}$ but synergism between them may also occur. ${ }^{6}$ In this study, the average quantity of alcohol consumed by habitual alcohol drinkers was only $177.2 \mathrm{~g} / \mathrm{wk}$. This amount may be insufficient to induce liver cirrhosis. No significantly increased risk of HCC was found for individuals only drinking alcohol. A moderately increased risk of $\mathrm{HCC}$ was observed among cigarette smokers who were nondrinkers and carried the $c 1 /$ c1 genotype of CYP2E1. However, a much greater risk was observed for those smokers who were also habitual alcohol drinkers and carried the $c 1 / c 1$ genotype. Whether the long-term habit of alcohol drinking may modify the effect of cigarette smoking on HCC development through induction of CYP2E1 in humans remains to be determined. However, this result suggests that intervention against alcohol drinking and cigarette smoking may be important for the prevention of $\mathrm{HCC}$ in high-incidence areas because the $\mathrm{c} 1 / \mathrm{c} 1$ genotype of CYP2E1 is present in a majority of persons.

Although we report a significant association between the genetic polymorphisms of CYP2E1 and risk of HCC, the estimates of relative tisks for developing $\mathrm{HCC}$ associated with various CYP2E1 genotypes may not be precise because of the small sample size. Because this is the first report on the role of CYP2E1 in the development of HCC, the findings of this study remain to be confirmed in the Chinese population as well as in other ethnic groups.

\section{References}

1. Yu MW, Chen $\mathrm{CJ}$. Hepatitis $B$ and $C$ viruses in the development of hepatocellular carcinoma. Crit Rev Oncol Hematol 1994;17:71-91.

2. Yu MW, You SL, Chang AS, Lu SN, Liaw YF, Chen CJ. Association between hepatitis $C$ virus antibodies and hepatocellular carcinoma in Taiwan. Cancer Res 1991;51:5621-5625.

3. Chang CC, Yu MW, Lu CF, Yang CS, Chen CJ. A nested casecontrol study on association between hepatitis $C$ virus antibodies and primary liver cancer in a cohort of 9775 men in Taiwan. $J$ Med Virol 1994;43:276-280.

4. Chen CJ, Zhang YJ, Lu SN, Santella RM. Aflatoxin $B_{1}$ DNA adducts in smeared tumor tissue from patients with hepatocellular carcinoma. Hepatology 1992;16:1150-1155.

5. Chen CJ, Yu MW, Wang CJ, Huang HY, Lin WC. Multiple risk factors of hepatocellular carcinoma: a cohort study of 13737 male adults in Taiwan. J Gastroenterol Hepatol 1993;8 (Suppl):S83-S87. 
6. Chen CJ, Liang KY, Chang AS, Chang YC, Lu SN, Liaw YF, Chang WY, Sheen MC, Lin TM. Effects of hepatitis B virus, alcohol drinking, cigarette smoking and familial tendency on hepatocellular carcinoma. Hepatology 1991;13:398-406.

7. Yu MW, Chen CJ, Luo JC, Brandt-Rauf PW, Carney WP, Santella RM. Correlations of chronic hepatitis $B$ virus infection and cigarette smoking with elevated expression of neu oncoprotein in the development of hepatocellular carcinoma. Cancer Res 1994;54:5106-5110.

8. Yu MC, Tong MJ, Govindarajan S, Henderson BE. Nonviral risk factors for hepatocellular carcinoma in a low-risk population, the non-Asians of Los Angeles County, California. J Natl Cancer Inst 1991;83:1820-1826.

9. Yu MW, Chen CJ. Elevated serum testosterone levels and risk of hepatocellular carcinoma. Cancer Res 1993;53:790-794.

10. Guengerich FP, Shimada T. Oxidation of toxic and carcinogenic chemicals by human cytochrome P450 enzymes. Chem Res Toxicol 1991; 4:391-407.

11. Mannervik B, Danielson UH. Glutathione transferases: structure and catalytic activity. Crit Rev Biochem Mol Biol 1988;23:281337 .

12. Nakachi K, Imai K, Hayashi SI, Kawajiri K. Polymorphisms of the CYP1A1 and glutathione S-transferase genes associated with susceptibility to lung cancer in relation to cigarette dose in a Japanese population. Cancer Res 1993;53:2994-2999.

13. Bell DA, Taylor JA, Paulson DF, Robertson CN, Mohler JL, Lucier GW. Genetic risk and carcinogen exposure: a common inherited defect of the carcinogen-metabolism gene glutathione S-transferase M1 (GSTM1) that increases susceptibility to bladder cancer. J Natl Cancer Inst 1993;85:1159-1164.

14. Brockmoller J, Kerb R, Drakoulis N, Staffeldt B, Roots I. Glutathione S-transferase $\mathrm{M} 1$ and its variants $A$ and $B$ as host factors of bladder cancer susceptibility: a case-control study. Cancer Res 1994; 54:4103-4111.

15. Sivaraman L, Leatham MP, Yee J, Wilkens LR, Lau AF, Marchand LL. CYP1A1 genetic polymorphisms and in situ colorectal cancer. Cancer Res 1994;54:3692-3695.

16. Takahashi T, Lasker JM, Rosman AS, Lieber CS. Induction of cytochrome P-4502E1 in the human liver by ethanol is caused by a corresponding increase in encoding messenger RNA. Hepatology 1993;17:236-245.

17. Guengerich FP, Kim DH, Iwasaki M. Role of human cytochrome P-450 IIE1 in the oxidation of many low molecular weight cancer suspects. Chem Res Toxicol 1991;4:168-179.

18. O'Neill IK, Chen J, Bartsch $\mathrm{H}$. Relevance to human cancer of $\mathrm{N}$ nitroso compounds, tobacco and mycotoxins. Publication no. 105. Lyon, France: International Agency for Research on Cancer, 1991.

19. Tsutsumi M, Matsuda $Y$, Takada A. Role of ethanol-inducible cytochrome P-450 2E1 in the development of hepatocellular carcinoma by the chemical carcinogen, $\mathrm{N}$-nitrosodimethylamine. Hepatology 1993;18:1483-1489.

20. Kato S, Shields PG, Caporaso NE, Hoover RN, Trump BF, Sugimura H, Weston A, Harris CC. Cytochrome P45OIIE1 genetic polymorphisms, racial variation, and lung cancer risk. Cancer Res 1992;52:6712-6715.

21. Uematsu F, Kikuchi H, Motomiya M, Abe T, Sagami I, Ohmachi $T$, Wakui A, Kanamaru R, Watanabe M. Association between restriction fragment length polymorphism of the human cyto- chrome P450lJE1 gene and susceptibility to lung cancer. Jpn J Cancer Res 1991;82:254-256.

22. Hirvonen A, Husgafvel-Pursiainen $K$, Anttila $S$, Karjalainen A, Vainio $H$. The human CYP2E1 gene and lung cancer: Dral and Rsal restriction fragment length polymorphisms in a Finnish study. Carcinogenesis 1993;14:85-88.

23. Maezawa $Y$, Yamauchi $M$, Toda $G$. Association between restriction fragment length polymorphism of the human cytochrome P450llE1 gene and susceptibility to alcoholic liver cirrhosis. Am J Gastroenterol 1994;89:561-565.

24. Hayashi SI, Watanabe J, Kawajiri K. Genetic polymorphisms in the $5^{\prime}$-flanking region change transcriptional regulation of the human cytochrome P450llE1 gene. J Biochem 1991;110:559 565.

25. Kato S, Shields PG, Caporaso NE, Sugimura H, Trivers GE, Tucker MA, Trump BF, Weston A, Harris CC. Analysis of cytochrome P450 2E1 genetic polymorphism in relation to human lung cancer. Cancer Epidemiol Biomarkers Prev 1994;3:515-518.

26. Anscombe FJ. On estimating binomial response relations. Biometrika 1956;43:461-464.

27. Shen FM, Lee MK, Gong HM, Cai XQ, King MC. Complex segregation analysis of primary hepatocellular carcinoma in Chinese families: interaction of inherited susceptibility and hepatitis $B$ viral infection. Am J Hum Genet 1991;49:88-93.

28. Yamazaki $\mathrm{H}$, Inui $\mathrm{Y}, \mathrm{Y}$ un $\mathrm{CH}$, Guengerich FP, Shimada T. Cytochrome $\mathrm{P} 4502 \mathrm{E} 1$ and $2 \mathrm{A6}$ enzymes as major catalysts for metabolic activation of $N$-nitrosodiakylamines and tobacco-related njtrosamines in human liver microsomes. Carcinogenesis 1992; 13:1789-1794.

29. Berger MR, Schmah। D, Edler L. Relationship between dose and risk reduction: statistical evaluation of a combination experiment with three hepatocarcinogenic N-nitrosamines in rats. In: O'Neill $\mathrm{IK}$, Chen J, Bartsch $\mathrm{H}$, eds. Relevance to human cancer of $\mathrm{N}$ nitroso compounds, tobacco and mycotoxins. Publication no. 105. Lyon, France: International Agency for Research on Cancer, 1991:311-317.

30. Koop DR, Tierney DJ. Multiple mechanisms in the regulation of ethanol-inducible cytochrome P-450llE1. Bioessays 1990;12: 429-435.

31. Rosenberg DW, Mankowski DC. Induction of cyp2e-1 protein in mouse colon. Carcinogenesis 1994;15:73-78.

32. Tsutsumi M, Takada A, Wang JS. Genetic polymorphisms of cytochrome P4502E1 related to the development of alcoholic liver disease. Gastroenterology 1994;107:1430-1435.

33. Adami H-O, Hsing AW, McLaughlin JK, Trichopoulos D, Hacker D, Ekbom A, Persson I. Alcoholism and liver cirrhosis in the etiology of primary liver cancer. Int J Cancer 1992;51:898-902.

34. Lieber CS, Garro A, Leo MA, Mak KM, Worner T. Alcohol and cancer. Hepatology 1986;6:1005-1019.

\section{Received December 8, 1994. Accepted June 5, 1995}

Address requests for reprints to: Chien-Jen Chen, Sc.D., Institute of Epidemiology, College of Public Health, National Taiwan University, No. 1 Jen-Ai Road, Section 1, Taipei 10018, Taiwan. Fax: (886) 2 351-1955.

Supported by grants DOH-H7707, DOH-H7903, DOH-H8003, DOH$\mathrm{H} 8103$, and DOH-H8203 from the Department of Health, Executive Yuan; grant NSC83-0412-B-002-256 from the National Science Council of the Republic of China; and grant ESO 5116 from the National Institutes of Health. 